\title{
Optimizing Utilization of Nypa Sap as Bioethanol Basic Materials for the Rural Community in Increasing the National Economic Growth
}

\author{
Warsono El Kiyata*, Yunida Munibaha, Elmus Rahmab, Yusron Mubarok ${ }^{\mathrm{c}}$ \\ a Jenderal Soedirman University, HR. Boenyamin Street 708, Purwokerto, Indonesia \\ b State Polytechnic of Bandung, Gegerkalong Hilir Street, Ciwaruga Villege, Bandung, Indonesia \\ cYogyakarta State University, Colombo Street Karang Malang, Yogyakarta, Indonesia
}

\begin{abstract}
Nypa has a relatively big potential as raw material for bioethanol. Total area of nypa plants in Indonesia is 700,000 hectare. Utilization of nypa sap in Indonesia are still not optimal because of the low interest and ability to process it to be other useful product. The rural community tends to only process nypa sap into sugar, but the quality of the sugar produced is very less because the salt is still contained in the sap. So the price is cheaper than other sugar. Utilization of nypa sap needs to be done by turning them into other useful product such as bioethanol to strengthen the Indonesian economic sectors. The method of data collection are used in this paper is the library research. This research use descriptive qualitative method. The analysis used in this research is a descriptive analysis. Based on the study, nypa sap is able to produce seven types of biofuels that can replace the fossil fuels, such as nypa bioethanol 100\%; nypa biokerosene 70\%; nypa biopertamax 95\% with pertamax plus 5\% ethanol; biopremium e20 nypa $80 \%$ with gasoline plus $20 \%$ ethanol; biopremium e85 nypa $25 \%$ with gasoline plus $85 \%$ ethanol, biodiesel and gliserin biodiesel nypa plus CPO (Crude Palm Oil). Calculation of bioethanol production from nypa sap each year is 3 million kL. Strategic steps that should be done in utilizing the nypa sap for the rural community, include: 1) socialize the utilization of nypa sap as a raw material for bioethanol; 2) give the demonstration and practice the process to make bioethanol from nypa sap; 3) establish the reference industrial; 4) grant the loan or capital; 5) grant the supporting production equipment and technology; and 6) monitoring and evaluation.
\end{abstract}

Keywords: bioethanol, nypa sap, the rural community

\footnotetext{
Corresponding author: Tel: +6287829540243

E-mail: warsono.el.kiyat@gmail.com
} 


\section{Introduction}

Recent decades the rate of world oil price continued to increase. It causes oil reserves are declining. The situation is contrast to the energy requirements that have increased (Agus 2000).

More than $80 \%$ of world energy needs met by fossil fuels derived from petroleum and natural gas (Gozan et al. 2007). Based on the data analysis of the Indonesian Petroleum Association (IPA), the beginning of 2004 oil production reached 1.11 million barrels per day, then at the end of 2007 fell to 970 thousand barrels per day. This condition requires Indonesia to reduce dependence on oil and find alternative energy sources (Diana et al. 2010).

Indonesia has a lot of plants that can be used as the base material of bioethanol, one of which is the sap of nypa plants. The area of nypa plants in Indonesia, 10\% of the tidal area of 7 million ha, or about 700,000 ha. Spread covers an area of Sumatra, Kalimantan, Java, Sulawesi, Maluku and Irian Jaya (Rachman and Sudarto 1992).

Rural communities is one of the elements that influence the growth of the national economy. Relation to the energy sector, the village has a high prospect in realizing strengthening the energy sector in Indonesia. The way is to carry out agricultural activities which can then be followed up through the use of commodity crops to be processed into biofuels.

Most of the plants nypa in Indonesia has not been used at all by the people of the village, only a small portion is used for sugar. According to Mukti (2012), rural communities tend to cultivate nypa sap into sugar product, but the quality of the sugar produced is very less because the salt content is still contained in the sap. So the selling price is cheaper compared to other sugars. In line with Tresnawati (2009), obtained from sugar nypa sap has a slightly salty taste and less preferred by consumers, thus processing the sap into sugar is not maximal. Potential of nypa sap itself can still be developed to be processed into bioethanol that can improve people's income since the price of bioethanol is much higher than the price of nypa sugar. It certainly can improve the general welfare of the artisans which currently processes nypa into sugar.

The purpose of this paper are: 1) knowing the bioethanol production process from nypa sap; 2) describing the potential of bioethanol from nypa sap in strengthening the national economy; 3) explaining the roles of government in overcoming the energy sector of national; 4) knowing calculation of bioethanol production outlook nypa sap; and 5) explaining the strategic move production of bioethanol from nypa sap for sustainable rural communities.

\section{Material and Method}

\subsection{Writing design}

This paper describes the process of the production of bioethanol from nypa sap, the potential of bioethanol from nypa sap in strengthening the national economy, the role of government in addressing the nation's energy sector, the calculation prospect in the production of bioethanol from nypa sap and strategic step production of bioethanol from nypa sap for rural communities in sustainable.

\subsection{Data coollection method}

Data collection methods used in this paper is the research library or the study of literature relevant to the theme that the author adopted well through scientific journals, papers, printed books, e-books, theses and internet media with fixed data sources.

\subsection{Data analysis}

Writing the data obtained in the data collection phase was analyzed using descriptive analysis method. Author developed the idea in the discussion based on the data that has been obtained, the studies in the literature that use of any existing problems such as assumptions and then made a generalization of the discussion as a result of the synthesis in order to support the idea that authors have to offer. Based on the analysis carried out in the discussion of conclusions obtained as a generalization of the discussion. Decision conclusions by the author consists of several stages: 1) analyzing problems with studying literature; 2) identifying problems based on existing data; and 3) finding alternatives in problem solving.

Suggestions addressed in order to follow up on the conclusions there. Follow the advice in the form of operational nature that can be done to enhance activity further studies have been conducted. 


\section{Result and Discussion}

\subsection{Production of bioethanol}

In general, the production of bioethanol technology includes 4 (four) series of processes, namely: preparation of raw materials, fermentation, distillation and purification (Bustaman 2008).

\subsubsection{Preparation of raw materials}

Preparation of raw materials vary depending on the raw material itself, but are generally divided into several processes. On materials that contain simple carbohydrates are sugars such as various kinds of juice, sugar cane, then stay tapped or extract sugar.

3.1.2 Fermentation processing

The fermentation process is often defined as the process of the breakdown of carbohydrates and amino acids anaerobically, that is without the need of oxygen. Compounds that can be broken down in the fermentation process is mainly carbohydrates, while amino acids can only be fermented by some certain types of microbes. Carbohydrates are the main substrates which are broken in the process of fermentation. Carbohydrates will first be broken down into simple sugars, namely hydrolysis which polysaccharides converted into glucose. Furthermore, glucose will be broken down into other compounds depending on the type of fermentation. One example is the fermentation of glucose into alcohol through the Embden-Meyerhof-Parnas (EMP) which is conducted by the yeast, such as Saccharomyces cerevisiae. Some groups such as Zymomonas mobillis bacteria can ferment glucose into alcohol through the EntnerDoudoroff (ED) (Fardiaz 1989).

\subsubsection{Distillation}

According Nurdyastuti (2008), the alcohol produced from the fermentation process usually still contain gases such as $\mathrm{CO}_{2}$ and aldehydes that need to be cleaned. $\mathrm{CO}_{2}$ gas in the fermentation typically achieve $35 \%$ volume, so as to obtain a good quality ethanol should be cleaned by filtering ethanol bound by $\mathrm{CO}_{2}$.

According Musanif (2008), distillation is the process of separating the components by boiling point, boiling point of pure ethanol at $78^{\circ} \mathrm{C}$, while the water is $100^{\circ} \mathrm{C}$, by heating the solution at a temperature range of 78 $100{ }^{\circ} \mathrm{C}$ would result in most of the ethanol evaporates, and through the condensing unit will be produced concentration of $95 \%$ ethanol by volume.

\subsubsection{Purification}

Distillation process results just have not fully pure ethanol alone, the process is still entrained water even in small quantities. Bioethanol is used as the fuel mixture for a vehicle that does not cause corrosion on the machine, then it must be completely dry or anhydrous. Therefore, it needs to be purified to remove water that is carried in bioethanol (Nurdyastuti 2008).

Bioethanol can be purified in two ways, chemistry and physics (Pranowo 2007). Limestone finely ground before use in order to faster water absorption. Comparison usage is 7 liters of bioethanol required for 2-3 kg of limestone. Mixture allowed to stand for 24 hours while stirring occasionally. After that the mixture is evaporated and condensed into a liquid again as ethanol $99 \%$ or more. The bioethanol can be mixed with gasoline or used pure. The weakness Limestone purification is the high loses amount of ethanol during purification process.

Purification method using synthetic zeolite physics, this purification process uses the principle of surface absorption. Different synthetic zeolite natural zeolite. Water that is absorbed slowly be released back to the water while the synthetic zeolite strongly bound. Purification of bioethanol should use synthetic zeolite 3A (size 3 angstrom) with excellence capable of binding more water. Use of synthetic zeolite advantages: (1) the time required is shorter, 12 hours and (2) loss of ethanol is only $10 \%$. But the price is more expensive than limestone, and has not been produced in Indonesia, therefore, the use of synthetic zeolite is more suitable for large-scale enterprises.

\subsection{Potential of bioethanol from nypa sap in improving national economic growth}

According to Wijaya (2011), ethanol is biofuel currently the most widely used. Ethanol is an alternative fuel which is prospective for several reasons such as not contributing to global warming, can be mixed with gasoline to $10 \%$ (E10) can be made from natural materials (biomass) such as cassava, maize and fruits. In substituting of MTBE (methyl tertiary butyl 
ether) potential. MTBE is a fuel additive which is toxic and nowadays is widely used in some countries. Nypa sap is a fluid that is sweet and has the potential to be made into sugar, both print sugar, nypa sugar or sugar syrup (Rachman and Sudarto, 1992).

Based on the research results held by Wardhanu (2011), nypa sap is able to produce seven types of biofuels are ethanol to biofuels to replace fossil fuels, including bioethanol content of $100 \%$ nypa, nypa biokerosene levels of 70\%, 95\% nypa biopertamax pertamax plus 5\% ethanol, nypa e20 biopremium $80 \%$ gasoline plus 20\% ethanol, 25\% nypa biopremium E85 gasoline plus $85 \%$ ethanol, biodiesel and nypa biodiesel glycerin plus CPO (Crued Palm Oil). The nypa of the products such as bioethanol content of $100 \%$ and $70 \%$ of low grade bioethanol as a substitute for kerosene biokerosene which has the advantage of blue flame. This is more efficient oil heat faster 1:6 /cook. 100\% bioethanol substituted with fossil fuels E10-20 to the premium (petrol) into premium bio fuel which has the advantage of high octane grade and environmentally friendly, as well as product types $100 \%$ bioethanol fuel that is substituted with E5 pertamax biopertamax produce one ingredient fuel which has the advantage of high octane fuel grade and environmentally friendly.

\subsection{The role of government in addressing the national energy sector}

Indonesia as a country that ever had great energy crisis and realizing the adverse effects of fossil fuel emissions, has made concrete steps such as policy and action on the ground, although for the latter steps are still experiencing a lot of obstacles. The steps that have been taken by the government include:

\subsubsection{Promoting an increase in the role of green energy}

Wijaya (2011) said, in 2025 the role of green energy (solar energy, wind, water, etc.) will be increased to $4.4 \%$ with $1.335 \%$ share of biofuels. Demand for biofuels will be a very big challenge for the government, the public, the energy users and other stakeholders, particularly from the agricultural sector is that they not only produce food, but also need to produce energy and regulating trade system. For society's increased share of biofuels use must also be coupled with increased awareness of the importance and role of biofuels, namely the substitution of environmentally friendly fossil fuel demonstrating a high work cheap and renewable.

\subsubsection{Issued presidential regulation 5 of 2006}

This regulation states that the role of renewable energy sources began to be increased where bio-fuels (biofuels) in 2025 targeted to reach at least $5 \%$ of the total national energy demand (Kamarudin 2000). Government seeks to solve the energy problems the possibility of trouble in the future by promoting the use of Biofuel (BBN), which comes from plants as a substitute for fossil fuel that has been used (Tim Nasional Pengembang $B B N$ 2008). In 2009, the government is aggressively promote the use of biofuels for energy saving and environmental protection in all provinces in Indonesia (BPPP 2009). This is in line with Nurianti (2007) that in the period 2007-2010, the government is targeting to replace 1.48 billion liters of gasoline with bioethanol in accordance with Government Regulation No.5/2006. Estimated needs of bioethanol will increase by $10 \%$ in $2011-2015$, and $15 \%$ in 2016-2025. In the period 2007-2010 during the first 3 years of government requires an average of 30.833 million liters of bioethanol/month. Currently new bioethanol can be supplied as much as 137000 liters per month $(0.4 \%)$.

\subsubsection{Guarantee of energy supply}

In the Year 2012, the government ensures energy supply by issuing budget for fuel subsidy (fuel oil) is estimated at about Rp 216 trillion, or more than is set out in the 2012 state budget only Rp 137 trillion (Ministry of Energy 2012).

\subsubsection{Issued UU No.30 of 2007}

Government issued Law No.30 of 2007 on Energy, which explains that all the challenges in the management of national energy must be mapped to either the Kebijakan Energi Nasional (KEN) prepared by the National Energy Board and the Rancangan UndangUndang Energi Nasional (RUEN) and Rancangan Undang-Undang Energi Daerah (RUED) compiled by the Central Government and Local Government Provincial and District (Kemen ESDM 2012). 


\subsubsection{Holding the annual meeting of national energy management}

In the Year 2012, the government held a National Energy Management Annual Meeting with the theme "Ketahanan Energi untuk Ekonomi Berkelanjutan". The meeting consisted of two activities, in the form of seminars and exhibitions. The purpose of this meeting is to evaluate energy policy and national energy management planning, and to improve coordination of the various stakeholder communication energy sector in order to accelerate the implementation of energy policy and related policies across sectors (Kemen ESDM 2012).

\subsection{Bioethanol production calculation of nypa sap in Indonesia}

Agus (2009) calculated the production of bioethanol from nypa sap. Assumed to average each frond nypa sap as much as $0.5 \mathrm{~L}$ per day. Every tree can be tapped up to 3 months. During the 1-year average productivity per nypa is equal to:

$$
=0.5 \mathrm{~L} / \text { day } \mathrm{x} 90 \text { days }=45 \mathrm{~L} / \text { year }
$$

An effective amount of nypa trees was 3000 trees per hectare and the meeting then the nypa trees will not result in virgin. Not 100\%, nypa trees within field generating virgin, usually around $40 \%$, thus, the resulting sap:

$$
=40 \% \times 3000 \times 45 \mathrm{~L}=54,000 \mathrm{~L} / \mathrm{ha} / \text { year }
$$

If sap is used for bioethanol production, the possibility of the resulting alcohol content is $6-7 \%$, although there are some microbes that are resistant to 9\% (volume) and can theoretically produce up to $13 \%$ vol, but the most likely is a $6-7 \%$ (volume) thus:

$$
=54,000 \times 7 \%=3780 \mathrm{~L} / \mathrm{ha} / \text { year }
$$

Area of about 0.75 to 1.35 million hectares of forest in Indonesia's nypa has the potential to produce bioethanol for:

$=3780 \mathrm{~L} / \mathrm{ha} \times 0.75$ million $=2840$ million liters $=$ 2.84 million $\mathrm{kL}$
According to Agus (2009), it can be achieved if the nypa forest in Indonesia is well managed. Currently the majority of people living in the coastal area do not understand the correct nypa sap tapping technique. In addition, the public is not really aware that the nypa can produce sap that could actually be used.

\subsection{Strtegic steps of utilization nypa sap of bioethanol production for sustainable rural communities}

We need some strategic steps in implementing the use of bio-ethanol from nypa sap. The hope that people can start a business based bioethanol production in a sustainable manner so that the nypa sap increased national economy can be achieved. As these measures include:

\subsubsection{Socialization nypa sap utilization as raw material bioethanol}

This stage is the provision of information related to bioethanol from nypa sap and its potential. Besides explaining processing procedures nypa sap into bioethanol.

\subsubsection{Demo and direct practice of bioethanol production from nypa sap}

Carry out workshops and intensive training for the community production of bioethanol from nypa sap. Testing and evaluation of related information and material that has been accepted by the community was conducted to determine how much progress of understanding. Held a contest based products bioethanol from nypa sap in improving people's motivation.

\subsubsection{Establishment of industry reference}

Establishment of industrial bioethanol nypa sap is done as an example / reference for coastal communities to ease the process of opening the business / home industry. Periodic industry monitoring efforts conducted as monitoring and evaluating the progress of the bioethanol industry for the nypa sap. 


\subsubsection{Provision of infrastructure industries}

At this stage, carried as working capital lending bioethanol from nypa sap for the community and implement community development efforts as business mentoring facility. In addition, the provision of production support tools done to improve the effectiveness and efficiency of the production of products, and to provide an explanation and application of the latest technology in addressing problems/deficiencies that occur during production.

\subsubsection{Monitoring and evaluation effort of bioethanol from nypa sap}

To supervise and provide recommendations for the advancement of the industry and have regular meetings as a means to improve business insight discussion of coastal communities.

\subsubsection{Provision product marketing incentives}

Final state is done by giving information network both inside and outside the city to facilitate the distribution of products. In addition, specific training is held on a good way of marketing products and effective.

\section{Conclusion}

In general, the production of bioethanol technology includes 4 (four) series of processes: preparation of raw materials, fermentation, distillation and purification. Bioethanol from nypa sap potentially be used to support national economic growth. Calculation of nypa sap production of bioethanol produced as many as 2.84 million kL per year. Bioethanol from nypa sap has greater prospects for development when compared with other commodity-producing bioethanol. The Government has issued a concrete policy and activities that can support the growth of the national economy in addressing the nation's energy sector. The necessary strategic steps in the utilization of nypa sap into bioethanol include: 1) Socialization nypa sap utilization of bio-ethanol as a raw material; 2) demo and hands-on production of bioethanol from nypa sap; 3) establishment of industry references; 4) the provision of facilities and infrastructure industries; 5) monitoring and evaluation efforts bioethanol from nypa sap; and 6) provision of product marketing facilities.
Suggestions that can be conveyed in this paper is an effort in the utilization of nypa sap into bioethanol required to produce maximum effort from all concerned. Need to be done the continued research about bioethanol from nypa sap on pilot scale. In addition, the use of bioenergy through savings and wise strict controls and the development of more environmentally friendly biofuels and renewable nature.

\section{Acknowledgements}

The authors acknowledge that during the writing process of this paper would have not finished without the help and big support from colleagues of our organization, university and government.

\section{References}

Agus, S.D. (2000) Cadangan Energi. Kebutuhan Energi dan Teknologi Masa Depan. Diskusi Sehari dalam Bidang Teknologi Masa Depan yang Ramah Lingkungan, Jakarta.

Agus, H. (2009) Indonesia: 3 Juta Kiloliter Bioetanol Potensial dari Tanaman Nipah. Avaliabel from, http://agus.wordpress.com.

Badan Penelitian dan Pengembangan Pertanian. (2009) Tanaman Perkebunan Penghasil Bahan Bakar Nabati (BBN). Pusat Penelitian dan Pengembangan Perkebunan. Badan Penelitian dan Pengembangan Pertanian, IPB Press, Bogor.

Bustaman, S. (2008) Strategi pengembangan bio-etanol berbasis sagu di Maluku. Perspektif, Vol. 7(2): 65 - 79.

Diana, U.E., Y. Zetra., A. Wahyudi \& R.Y.P. Burhan. (2010) Kajian Ekstraksi Alifatik Produk Pencairan Batubara Low Rank Kalimantan Timur. Research Report. Unit Riset Geokimia Organik dan Senyawa Prekursor, Chemical Department. Institut Sepuluh Nopember, Surabaya.

Fardiaz, S. (1989) Mikrobiologi Pangan. Departemen Pendidikan dan Kebudayaan Direktorat Jenderal Pendidikan Tinggi. Pusat Antar Universitas Pangan dan Gizi, Institut Pertanian Bogor.

Gozan, Misri \& Samsuri. (2007) Sakarafikasi dan fermentasi bagas menjadi etanol menggunakan enzim selulase dan enzim sellobiase. Jurnal Teknologi, Vol. 3: 209-215.

Kamarudin, A. (2000) Utilization of Environmentally Friendly Natural Energy to Promote Agro-based Industry. Laporan akhir proyek grassroot bantuan ODA pemerintah jepang-CREATA-IPB.

Kemen ESDM. (2012) Pertemuan Tahunan Pengelolaan Energi Nasional "Ketahanan Energi untuk Ekoknomi Berkelanjutan". Kementerian Energi dan Sumber daya Mineral, Jakarta.

Mukti, A.A. (2012) Pengaruh Konsentrasi Starter dan Lama Inkubasi terhadap Produksi Bioetanol dari Nira Nipah Menggunakan Saccharomyces cervisiae. Thesis. Fakultas Pertanian, Universitas Jenderal Soedirman, Purwokerto.

Musanif, J. (2008) Bioetanol. Jurnal Bio-fuel.

Nurdyastuti, I. (2008) Teknologi proses produksi bio-ethanol. Journal prospek Pengembangan Bio-fuel: 75 - 81.

Nurianti. Y. (2007) Pasok Langsung ke Pertamina?. Avaliable from, http://www.trubus-online.com 
Pranowo. D.K. (2007) Bio-etanol 99,5\%, Murnikan saja dengan gamping. Avaliable from, http://www.trubus-online.com.

Rachman, A.K. \& Y. Sudarto. (1992) Nira Sumber Pemanis Baru. Kanisius, Yogyakarta.

Rahayu, E.S. \& K. Rahayu. (1988) Teknologi Pengolahan Minuman Beralkohol. PAU Pangan dan Gizi UGM, Yogyakarta.

Tim Nasional Pengembangan BBN. (2008) Bahan Bakar Nabati Bahan Bakar Alternatif dari Tumbuhan Sebagai Pengganti Minyak Bumi dan Gas. Eka Tjipta Foundation. Penebar Swadaya, Jakarta.

Tresnawati, H. (2009) Motivasi Wanita Perajin Gula Nipah Dalam Meningkatkan Pendapatan Rumah Tangga di Desa Nusadadi, Kecamatan Sumpiuh, Kabupaten Banyumas. Skripsi. Fakultas Pertanian, Unsoed Purwokerto.

Wardhanu, A.P. (2011) Potensi Pengembangan Bioenergi di Kalimantan Barat. Avaliable from, http://apwardhanu.wordpress.com.

Wijaya, K. (2011) Biofuel di Indonesia: Prospektof, Perspektif dan Strategi Pengembangannya. paper disseminated in National Seminar, Unsoed, Purwokerto. 